УДК 336.71

Мостовенко Н.А., к.е.н, доцент

Mostovenko N., Candidate of Economic Sciences, Associate Professor, https://orcid.org/0000-0002-2050-1529

Коробчук T.I., к.е.н., доцент

Korobchuk T. Candidate of Economic Sciences, Associate Professor, https://orcid.org/0000-0002-0356-4157

\title{
КРЕДИТНА СКЛАДОВА РИНКУ БАНКІВСЬКИХ ПОСЛУГ: ТЕНДЕНЦІЇ ТА ПЕРСПЕКТИВИ ЗРОСТАННЯ
}

\author{
Луиький національний технічний університет
}

\begin{abstract}
Актуальність банківських кредитних послуг та їх значимий вплив на розвиток будь-яких економічних систем є неодмінною реалією сьогодення. Тому ринок банківських послуг працює на всіх рівнях економічного розвитку - від звичайного домогосподарства i аж до макрорівня. Вітчизняна банківська система пройшла очищення через скорочення сумнівних банків, відновилась та виходить 3 кризового періоду. Тому стаття присвячена саме кредитній складовій ринку банківських послуг.

У проведеному дослідженні розглянуто поняття «банківська послуга», на основі теоретичних аспектів вітчизняних дослідників, подано авторський підхід до цього поняття. Досліджено проникність вітчизняного ринку кредитних послуг. Для проведення дослідження виділено спеціальні показники: частки кредитів, наданих банками резидентам клієнтської доступності кредитних послуг, валових кредитів депозитних корпорацій, кредитів резидентам (крім депозитних корпорацій) у ВВП, кількість структурних підрозділів банків на 100 тис. економічно активного населення та процентну маржу. Розраховано показники стану ринку фінансових послуг України за кредитними операціями банківського сектору та здійснено аналіз на відповідність критеріям Групи Світового банку. Проаналізовано результат діяльності банків у абсолютному вираженні - чистий процентний дохід. Зроблено висновки про тенденції та перспективи зростання кредитної складової ринку банківських послуг.

Ключові слова: банки, ринок банківських послуг, кредит, кредитні послуги банків, фінансовий ринок, фінансове забезпечення, сочіально-економічний розвиток.
\end{abstract}

\section{CREDIT COMPONENT OF THE MARKETING SERVICES MARKET: TRENDS AND GROWTH PROSPECTS}

\author{
Lutsk National Technical University
}

The relevance of banking credit services and their significant impact on the development of any economic system is an indispensable reality of today. Therefore, the banking market operates at all levels of economic development - from the ordinary household to the macro level. The domestic banking system has been cleaned up due to the reduction of dubious banks, has recovered and is coming out of the crisis period. Therefore, the article is devoted to the credit component of the banking market.

The study considers the concept of "banking service", based on theoretical aspects of domestic researchers, presents the author's approach to this concept. The permeability of the domestic credit services market is studied. To conduct the study, special indicators were identified: the share of loans granted by banks to residents of customer access to credit services, gross loans to deposit-taking corporations, loans to residents (excluding deposit-taking corporations) in GDP, number of bank divisions per 100,000 economically active population and interest margin. According to the results of the analysis, a slowdown in GDP growth and a significant reduction in the total volume of gross loans generally issued by deposit-taking corporations were noted. It is noted that the permeability of the credit market and the reproductive role of credit in the economic system is significantly narrowed.

The indicators of the state of the financial services market of Ukraine for credit operations of the banking sector were calculated and the analysis for compliance with the criteria of the World Bank Group was performed. It was found that in terms of the share of loans granted to resident banks, the Ukrainian market at the beginning of the analyzed period approached the markets with high per capita incomes, and gradually lost its position, being among the indicator typical of countries with "below average". In terms of customer availability of banking services, including credit, we see a downward trend. This indicator will gradually lose its relevance for market assessment, due to the widespread introduction of digital services by domestic banks, the penetration of Internet banking and the course to maximize the overall range of remote banking services, based on widespread innovation in the banking segment, digital customer verification and more. In terms of interest margins, or "spread of interest 
rates", the domestic credit market is moving confidently towards low-income countries. The result of banks' activity in absolute terms - net interest income is analyzed. Conclusions are made about the tendencies and prospects of growth of the credit component of the banking services market.

Key words: banks, banking services market, credit, bank lending services, financial markets, financial security, socio-economic development

Постановка проблеми у загальному вигляді і її зв'язок $з$ важливими науковими та практичними завданнями. Сучасні реалії розвитку соціально-економічних систем підкреслюють актуальність впливу банківських кредитних послуг на всі економічні процеси. Тому оптимізація функціонування обгрунтованого та ефективного кредитного механізму має вплив не лише на активізацію позитивної дії кредитних відносин на обсяг та структуру грошової маси в країні, а і на забезпечення потреби в додаткових джерелах фінансування розширеного відтворення. 3 однієї сторони, це підтримується підвищенням ефективності кредитних операцій банків, які були і є основним джерелом прибутковості. 3 іншої, це - реалізація кредитних відносин, що забезпечується дохідністю кожної кредитної операції (проєкту).

Аналіз останніх досліджень і публікацій, в яких започатковано розв'язання даної проблеми. У науковій літературі питанням висвітлення сутності, функцій та принципів банківських кредитних послуг присвячені праці У. Владичина, В. Вовка, I. Гуцала, В. Короля, Л. Кузнєцової, О. Лаврушина, В. Міщенка, С. Науменкової, Г. Панової, та ін. Теоретичні та методичні аспекти оцінки ефективності фінансового ринку, ефективності кредитних послуг, в тому числі й елементи понятійнокатегоріального апарату відображені в працях А. Гальчинського, Т. Гірченко, І. Гуцала, С. Мочерного, С. Єрохіна, А. Ніколаєвої, А. Мороза, О. Олійника, С. Реверчука, П. Саблука, А. Сміта, О. Стороженко, М. Туган-Барановського, Н. Шелудько та ін.

Так, В.Король вважає, що кредитна послуга - це «...економічні відносини між кредитором (комерційним банком) i позичальником 3 приводу надання коштів останньому на умовах платності, строковості, обов'язкового повернення та матеріального забезпечення...» [1]. О. Стороженко та Т. Гірченко переконані, що банківська кредитна послуга - це «...розміщення залучених банком коштів шляхом їх надання в тимчасове користування або прийняттям зобов'язань про надання коштів у тимчасове користування на певних умовах....» [2]. А за визначенням НБУ, це «...розміщення залучених банком коштів шляхом їх надання в тимчасове користування, а також надання гарантій, поручительств, акредитивів, акцептів, авалів, розміщення депозитів, проведення факторингових операцій, фінансового лізингу, видача кредитів у формі врахування векселів, у формі операцій репо, будь-яке продовження строку погашення боргу, яке надано в обмін на зобов'язання боржника щодо повернення заборгованої суми, а також на зобов'язання на сплату процентів та інших зборів 3 такої суми (відстрочення платежу)...» [3]. Зазначимо, що у загальному ринку банківських послуг, ринок кредитних послуг може класифікуватися за кількома ознаками [4, с. 2627]: «за продуктовою структурою банківських послуг», «за результатами діяльності банківських установ», «за об'єктом купівлі-продажу». Отже, кредитні послуги банків формуються як особливий тип економічних відносин, головною ознакою яких $\epsilon$ одержання позичальниками, які в юридичній площині перед банками стають боржниками, погодженої з кредитором суми коштів, з умовою їх вчасного повернення та сплати відсотків за користування.

Цілі статті. Метою статті є дослідження клієнтського навантаження у секторі банківських послуг та характеристика кредитної складової ринку банківських послуг.

Виклад основного матеріалу дослідження 3 повним обгрунтуванням отриманих наукових результатів. Ринок банківських послуг, зокрема кредитних, відіграє важливу роль у фінансовому забезпеченні соціального й економічного розвитку на усіх рівнях, від конкретного домогосподарства чи СПД до макрорівня загалом. Слід зазначити, що нині банківський сектор фінансового ринку демонструє активне відновлення та вихід із кризового періоду, спричиненого уповільненням економічного 
зростання. Проте ситуація у банківському секторі зазнала змін ще задовго до уведення карантинних заходів внаслідок очищення банківської системи, причому продовжує скорочуватись не лише загальна кількість банківських установ, а й кількість їх структурних підрозділів (див. табл. 1).

Таблиця 1

Клієнтське навантаження на сектор банківських послуг

\begin{tabular}{|l|c|c|c|c|c|}
\hline \multicolumn{1}{|c|}{ Показники } & 2016 p. & 2017 p. & $2018 \mathrm{p}$. & 2019 p. & 2020 p. \\
\hline $\begin{array}{l}\text { Кількість банківських } \\
\text { установ }\end{array}$ & 117 & 93 & 82 & 75 & 73 \\
\hline $\begin{array}{l}\text { Регулятивний капітал, } \\
\text { млн. грн. }\end{array}$ & 109654,0 & 115817,6 & 126116,7 & $\begin{array}{c}150313, \\
8\end{array}$ & 182283,6 \\
\hline $\begin{array}{l}\text { Кількість діючих } \\
\text { структурних підрозділів } \\
\text { банківських установ } \\
\text { станом на кінець року, од. }\end{array}$ & 10316 & 9489 & 8509 & 8002 & 7134 \\
\hline $\begin{array}{l}\text { Кількість населення у віці } \\
15-70 \text { років, тис. осіб }\end{array}$ & 17672,7 & 17854,4 & 17939,5 & 18066,0 & 17644,1 \\
\hline $\begin{array}{l}\text { Кількість осіб на 1 } \\
\text { структурний підрозділ } \\
\text { банківської установи }\end{array}$ & 1713 & 1882 & 2108 & 2258 & 2473 \\
\hline $\begin{array}{l}\text { Частка непрацюючих } \\
\text { кредитів, \% }\end{array}$ & 23,70 & 54,54 & 52,85 & 48,36 & 41,00 \\
\hline
\end{tabular}

Як свідчать дані таблиці 1, результатом таких подій стало суттєве зростання чисельності клієнтів на структурні підрозділи банківських установ, а частка непрацюючих кредитів все ще продовжує бути високою.

У дослідженні Ніколаєвої А. М. зазначається, що у світовій практиці методики оцінювання кредитного ринку спираються на певні статистичні показники, як от: «...частка виданих комерційними банками кредитів у відсотковому відношенні до ВВП, кількість філій комерційних банків на 100 тис. дорослого населення, розмір спреду відсоткових ставок тощо» [5, с. 130]. Також у зазначеному дослідженні обгрунтовується теза про те, що країни з високим рівнем доходу на душу населення демонструють й високий рівень показників, що визначають стан розвитку фінансового ринку. Розглянемо, якою є проникність вітчизняного ринку кредитних послуг, що надаються банківським сектором фінансової системи за окресленим підходом, у реальний сектор економіки за допомогою таблиці 2.

Таблиця 2

Оцінка стану вітчизняного ринку фінансових послуг за критеріями Групи Світового банку, що грунтуються на показниках банківського сектору*

\begin{tabular}{|c|c|c|c|c|c|c|c|c|}
\hline Показники & 2013 p. & $2014 \mathrm{p}$. & $2015 \mathrm{p}$. & $2016 \mathrm{p}$. & 2017 p. & $2018 \mathrm{p}$. & 2019 p. & $2020 \mathrm{p}$. \\
\hline ВВП, млн. грн. & 1465198 & 1586915 & 1988544 & 2385367 & 2983882 & 3560596 & 3978400 & 4194102 \\
\hline - темп приросту, \% & & 8,31 & 25,31 & 19,96 & 25,09 & 19,31 & 11,73 & 5,42 \\
\hline \begin{tabular}{|l|} 
Валові кредити \\
депозитних \\
корпорацій, млн. грн. \\
\end{tabular} & 941631 & 1075438 & 1046304 & 1046576 & 1085303 & $\begin{array}{c}115928 \\
4\end{array}$ & 1050513 & 990071 \\
\hline - темп приросту, \% & - & 14,21 & $-2,71$ & 0,03 & 3,70 & 6,82 & $-9,38$ & $-5,75$ \\
\hline $\begin{array}{l}\text { Частка валових } \\
\text { кредитів депозитних } \\
\text { корпорацій у ВВП, \% }\end{array}$ & 64,27 & 67,77 & 52,62 & 43,87 & 36,37 & 32,56 & 26,41 & 23,61 \\
\hline - темп приросту, \% & - & 5,45 & $-22,36$ & $-16,61$ & $-17,10$ & $-10,48$ & $-18,90$ & $-10,60$ \\
\hline
\end{tabular}


Продовження таблиці 2

\begin{tabular}{|c|c|c|c|c|c|c|c|c|}
\hline 1 & 2 & 3 & 4 & 5 & 6 & 7 & 8 & 9 \\
\hline $\begin{array}{l}\text { Кредити резидентам } \\
\text { (крім депозитних } \\
\text { корпорацій), млн. грн. }\end{array}$ & 910782 & 1020667 & 981627 & 998682 & 1016657 & $\begin{array}{c}107313 \\
1\end{array}$ & 971871 & 948386 \\
\hline - темп приросту & - & 12,06 & $-3,82$ & 1,74 & 1,80 & 5,55 & $-9,44$ & $-2,42$ \\
\hline $\begin{array}{l}\text { Частка кредитів } \\
\text { резидентам (крім } \\
\text { депозитних корпорацій) } \\
\text { у ВВП, \% }\end{array}$ & 62,16 & 64,32 & 49,36 & 41,87 & 34,07 & 30,14 & 24,43 & 22,61 \\
\hline - темп приросту & - & 3,47 & $-23,25$ & $-15,19$ & $-18,62$ & $-11,54$ & $-18,95$ & $-7,44$ \\
\hline $\begin{array}{l}\text { Економічно активне } \\
\text { населення, тис. осіб }\end{array}$ & 20478,2 & 19035,2 & 17396,0 & 17303,6 & 17193,2 & 17296,2 & 17381,8 & 16917,8 \\
\hline - темп приросту, \% & - & $-7,05$ & $-8,61$ & $-0,53$ & $-0,64$ & 0,60 & 0,49 & $-2,67$ \\
\hline $\begin{array}{l}\text { Кількість діючих } \\
\text { структурних підрозділів } \\
\text { банківських установ, од. }\end{array}$ & 19290 & 15082 & 11871 & 10316 & 9489 & 8509 & 8002 & 7134 \\
\hline - темп приросту, \% & - & $-21,81$ & $-21,29$ & $-13,10$ & $-8,02$ & $-10,33$ & $-5,96$ & $-10,85$ \\
\hline $\begin{array}{l}\text { Кількість структурних } \\
\text { підрозділів банків на } \\
100 \text { тис. економічно } \\
\text { активного населення }\end{array}$ & 94,20 & 79,23 & 68,24 & 59,62 & 55,19 & 49,20 & 46,04 & 42,17 \\
\hline - темп приросту, \% & $-15,89$ & $-13,87$ & $-12,64$ & $-7,43$ & $-10,86$ & $-6,42$ & $-8,40$ & $-15,89$ \\
\hline Процентна маржа, \%** & 4,9 & 4,5 & 5,9 & 5,5 & 6,3 & 6,3 & 5,5 & 7,5 \\
\hline - темп приросту, \% & - & $-8,16$ & 31,11 & $-6,78$ & 14,55 & 0 & $-12,70$ & 36,36 \\
\hline
\end{tabular}

* Сформовано та розраховано авторами на основі даних НБУ [6].

**Значення показників обчислено на основі даних НБУ [7].

За результатами проведеного аналізу, насамперед варто відмітити уповільнення темпів приросту ВВП, причому показник 2020 року має найнижче значення упродовж усього досліджуваного періоду. Також спостерігаємо й суттєве скорочення загального обсягу валових кредитів, загалом виданих депозитними корпораціями, що найбільш критично зменшилися у 2019 році, та продовжили падіння й у 2020 році. Зауважимо, що суттєво звужується проникність кредитного ринку та відтворювальна роль кредиту в економічній системі. Маємо скорочення частки валових кредитів депозитних корпорацій по відношенню до ВВП майже утричі, порівняно із 2013 роком.

Проведемо аналіз розрахованих показників стану вітчизняного ринку фінансових послуг за кредитними операціями банківського сектору на відповідність критеріям Групи Світового банку. За часткою кредитів, наданих банками резидентам, Український ринок на початку аналізованого періоду наближався до ринків з високим рівнем доходів на душу населення, і поступово втратив свої позиції аж до показника 22,61\%, опинившись між показником, притаманним країнам з показниками «нижче середнього» зі значенням 44,4\% та «низьким», 3 показником $12,9 \%$ [5, с. 131]. За показником клієнтської доступності банківських послуг, зокрема кредитних, проаналізуємо показник кількості структурних підрозділів банків на 100 тис. економічно активного населення. В Україні цей показник демонструє тенденцію до зниження та загалом, станом на 2020 рік, зменшився майже удвічі, порівняно із 2013 роком. За своїм фактичним значенням він навіть вищий за показник, що відповідає країнам з «високим рівнем доходів» - 19,6 [5, с. 131]. Варто зауважити, що такий показник поступово втрачатиме свою актуальність для оцінки ринку, зважаючи на широке впровадження діджитал послуг вітчизняними банками, проникнення інтернет-банкінгу та курс на максимальне розширення загального спектру дистанційних банківських послуг, що грунтується на широкому впровадженні інновацій у банківський сегмент, можливості цифрової верифікації клієнта тощо.

Порівняння процентних ставок за наданими банками кредитами та залученими депозитами дозволяє оцінити прибутковість банківського бізнесу. Різниця вказаних 
ставок відома під назвою «процентної маржі». За показником процентної маржі, або «спреду відсоткових ставок» вітчизняний кредитний ринок упевнено рухається у бік країн 3 низьким рівнем доходу, оскільки розраховане значення цього показника перевищило рівень у 6,9\%, притаманний країнам з показниками «нижче середнього». Як справедливо зазначає Ніколаєва А.М.: «Чим нижчий дохід населення і відповідно нижче рівень економічного розвитку країни, тим ширша величина спреду відсоткових ставок в банківській системі таких країн, тобто 3 більшими втратами банківська система перетворює депозити домогосподарств на кредити підприємствам» [5, с. 131]. Ще одним чинником зростання процентної маржі є той факт, що банки нині не мають проблем із фондуванням, у його структурі переважає депозитна складова. За новими даними НБУ, на кінець вересня 2021 року частка коштів фізичних осіб та корпорацій у зобов'язаннях банків становила 83\%. Крім того, застосування облікової ставки з метою приборкання інфляційних процесів відразу позначається на зростанні ставок за кредитами, відтак і процентна маржа банків зростає.

Результатом діяльності банків у абсолютному вираженні є показник чистого процентного доходу, продемонстрований на рис. 1. Як бачимо, поряд із зростанням процентної маржі, значення показника чистого процентного доходу динамічно зростає, починаючи із 2015 року, а отже банківський сектор фінансового ринку має можливість для подальшого розвитку та виходить із кризового періоду.

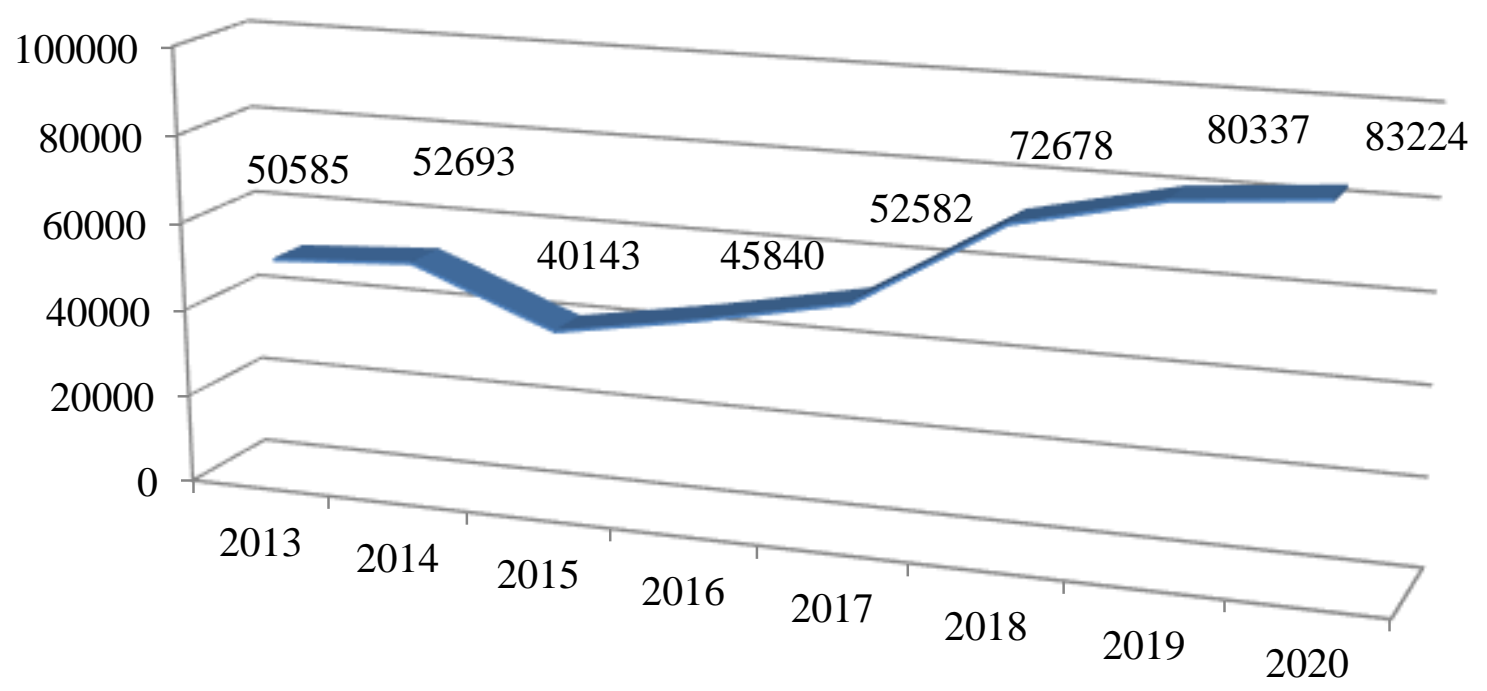

Рис. 1. Динаміка показника чистих процентних доходів депозитних корпорацій, млн. грн.

Для більш повної характеристики кредитної складової ринку банківських послуг розглянемо стан ринку банківського кредитування в розрізі основних суб'єктів реального сектору економіки - нефінансових корпорацій, що є його ключовими інституціями, діяльність яких безпосередньо пов'язана із виробництвом товарів для ринку та наданням послуг, що мають нефінансовий характер (див. рис. 2). 


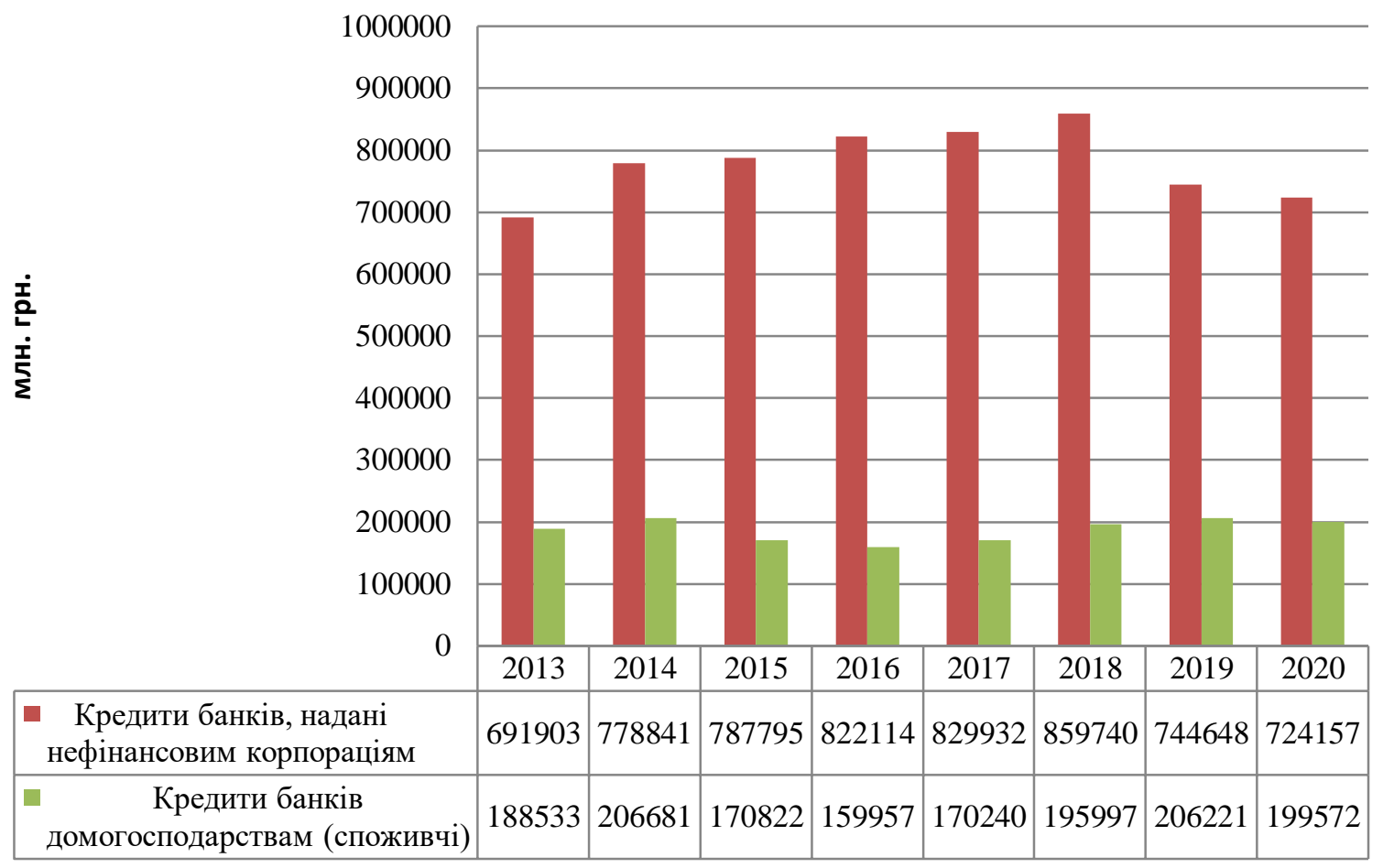

Рис. 2. Динаміка обсягів банківського кредитування за секторами економіки, млн. грн.

Представлені на рисунку 2 дані станом на 2019-2020 роки демонструють суттєве зниження обсягів кредитування депозитними корпораціями реального виробництва, яке навіть має нижче значення, ніж показник 2014 року, що теж відзначився складними політичними та соціальними подіями в Україні. Зазначену тенденцію яскраво помітно при співставленні обсягів кредитування із ВВП (див. табл. 3). Цей методологічний підхід прийнято використовувати при оцінці масштабів фінансового ринку загалом та його окремих складових зокрема.

Таблиця 3

Характеристика проникнення кредитних послуг банків в реальний сектор економіки *

\begin{tabular}{|l|c|c|c|c|c|c|c|c|}
\hline \multicolumn{1}{|c|}{ Показники } & 2013 & 2014 & 2015 & 2016 & 2017 & 2018 & 2019 & 2020 \\
\hline $\begin{array}{l}\text { Частка кредитів } \\
\text { нефінансовим } \\
\text { корпораціям у ВВП, \% }\end{array}$ & 47,22 & 49,08 & 39,62 & 34,46 & 27,81 & 24,15 & 18,72 & 17,27 \\
\hline- -темп приросту & - & 3,93 & $-19,28$ & $-13,00$ & $-19,30$ & $-13,19$ & $-22,48$ & $-7,75$ \\
\hline $\begin{array}{l}\text { Частка кредитів } \\
\text { домогосподарствам у } \\
\text { ВВП, \% }\end{array}$ & 13,21 & 13,31 & 8,79 & 6,85 & 5,84 & 5,65 & 5,34 & 4,92 \\
\hline- - темп приросту & - & 0,77 & $-33,93$ & $-22,14$ & $-14,75$ & $-3,25$ & $-5,42$ & $-7,84$ \\
\hline
\end{tabular}

*Сформовано та розраховано авторами на основі даних НБУ [6].

Зважаючи на те, що в Україні все таки відбувався приріст ВВП (див. табл.1), ситуація виглядає вкрай незадовільною, адже починаючи із 2015 року приріст частки кредитів, наданих нефінансовим корпораціям у ВВП, мав від'ємне значення.

Що стосується кредитів, наданих домогосподарствам, то їх обсяг хоч і показує певну висхідну динаміку у періоді 2016-2019 років, проте вона не є стійкою (див. табл.1), а обсяг такого кредитування теж не досягнув показника 2014 року. Аналізуючи, 
відповідно частку кредитів домогосподарствам у ВВП (див. табл. 3) теж спостерігаємо негативну тенденцію. Така частка продовжує знижуватися, а іiі значення у 4,92\% $є$ найнижчим за увесь досліджуваний період. Таким чином, незважаючи на зниження кредитних ставок за новими кредитами до рівня 13,1\% у 2020 році проти 17,0\% чи 17,2\% у 2018 році) досягти приросту обсягів кредитування не вдалося. Як суб'єктам господарювання, так і домогосподарствам необхідні додаткові стимули та наявність економічних перспектив не лише для відновлення кредитування, а й для реалізації його позитивного рушійного впливу на економічне зростання.

Висновки. Отже, кредитна послуга банків - це особливий тип економічних відносин, головною ознакою яких $є$ одержання позичальниками, які в юридичній площині перед банками стають боржниками, погодженої з кредитором суми коштів, 3 умовою їх вчасного повернення та сплати відсотків за користування. А основною характеристикою кредитної складової ринку банківських послуг є іiі проникність у реальний сектор економіки. Ця проникність характеризується спеціальними показниками: частками валових кредитів депозитних корпорацій, кредитів резидентам (крім депозитних корпорацій) у ВВП, кількістю структурних підрозділів банків на 100 тис. економічно активного населення та процентною маржею. За рівнем цих показників бачимо, що вітчизняний ринок банківських кредитних послуг рухається у бік країн з низьким рівнем доходу. Тому для забезпечення позитивних економічних перспектив всім суб'єктам господарювання, та й домогосподарствам просто необхідні додаткові стимули, особливо для відновлення кредитування.

\section{Список бібліографічного опису:}

1. Король В.А. Фінанси підприємств: навч. посібник. URL: https://buklib.net/books/25408/ (дата звернення 22.10.2021) 2. Стороженко О.О., Гірченко Т.Д., Шейко О.П. Кредитні операції банків на сучасному етапі економіки. Причорноморські економічні студіï. 2020. Випуск 52-2. с. 130. DOI https://doi.org/10.32843/bses.52-41

3. Офіційний сайт НБУ. URL: https://old.bank.gov.ua/control/uk/publish/article?art_id=123413 (дата звернення 23.10.2021)

4. Герасимчук 3. В., Гоманюк О. К. Розвиток регіональних ринків банківських послуг: теорія, методологія, практика : монограф. Луцьк : Вежа-Друк, 2016. 324 с.

5. Ніколаєва А.М. Теоретико-методологічні аспекти оцінки ефективності фінансового ринку. Економічний форум. 2021. № 3. C. 125-133. URL: file:///C:/Users/User/AppData/Local/Temp/ekonomichniy-forum-3-2021.pdf (дата звернення 24.10.2021)

6. Грошово-кредитна статистика. Кредити, надані депозитними корпораціями (крім Національного банку України). Офіційний сайт Національного банку України. URL: https://bank.gov.ua/ua/statistic/sector-financial/data-sectorfinancial\#1ms (дата звернення 24.10.2021).

7. Грошово-кредитна статистика. Фінансові ринки. Процентні ставки депозитних корпорацій (крім Національного банку України) за кредитами та депозитами. Офіційний сайт Національного банку України. URL: https://bank.gov.ua/ua/statistic/sector-financial/data-sector-financial\#2fs (дата звернення 24.10.2021).

\section{References:}

1. Korol' V.A. Finansy pidpryyemstv: navch. posibnyk. URL: https://buklib.net/books/25408/ (data zvernennya 22.10.2021) 2. Storozhenko O.O., Hirchenko T.D., Sheyko O.P. Kredytni operatsiyi bankiv na suchasnomu etapi ekonomiky. Prychornomors'ki ekonomichni studiyi. 2020. Vypusk 52-2. s. 130. DOI https://doi.org/10.32843/bses.52-41

3. Ofitsiynyy sayt NBU. URL: https://old.bank.gov.ua/control/uk/publish/article?art_id=123413 (data zvernennya 23.10.2021)

4. Herasymchuk Z. V., Homanyuk O. K. Rozvytok rehional'nykh rynkiv bankivs'kykh posluh: teoriya, metodolohiya, praktyka : monohraf. Luts'k : Vezha-Druk, 2016. 324 s.

5. Nikolayeva A.M. Teoretyko-metodolohichni aspekty otsinky efektyvnosti finansovoho rynku. Ekonomichnyy forum. 2021. № 3. S. 125-133. URL: file:///C:/Users/User/AppData/Local/Temp/ekonomichniy-forum-3-2021.pdf (data zvernennya 24.10.2021)

6. Hroshovo-kredytna statystyka. Kredyty, nadani depozytnymy korporatsiyamy (krim Natsional'noho banku Ukrayiny). Ofitsiynyy sayt Natsional'noho banku Ukrayiny. URL: https://bank.gov.ua/ua/statistic/sector-financial/data-sectorfinancial\#1ms (data zvernennya 24.10.2021).

7. Hroshovo-kredytna statystyka. Finansovi rynky. Protsentni stavky depozytnykh korporatsiy (krim Natsional'noho banku Ukrayiny) za kredytamy ta depozytamy. Ofitsiynyy sayt Natsional'noho banku Ukrayiny. URL: https://bank.gov.ua/ua/statistic/sector-financial/data-sector-financial\#2fs (data zvernennya 24.10.2021).

Дата подання публікації 20.10.2021p. 